\title{
University Students as Digital Migrants
}

\author{
CHERYL BROWN \\ Centre for Educational Technology, University of Cape Town
}

\begin{abstract}
South African university students are on the frontline of a global world. Whether they are attending university in the rural Eastern Cape or urban Johannesburg, the social practice of using Information and Communication Technologies (ICTs) has enabled virtual global mobility. The internet has opened up an opportunity for them to easily cross beyond the borders of South Africa and become part of an experience in another part of the world while the cellphone has facilitated this mobility anytime any place. This paper focuses on the students who are migrants into this digital world through analysis of their technology discourses and the role this has in how they engage with and within this digital environment. Using Gee's notion of big ' $D$ ' and little ' $d$ ' D(d)iscourses (1996), I have examined the meanings held by students in relation to technology. This analysis of language provides insights into students' educational and social identities and the position of globalisation and the information society in both facilitating and constraining their participation and future opportunities.
\end{abstract}

\section{Introduction}

The end of apartheid initiated an intense period of focus on social equity and redress post-1994. In higher education, this meant the restructuring of a "landscape that was largely dictated by the geo-political imagination of apartheid planners" (Department of Education, 1999, p. 11). While the participation in higher education and diversity of the student cohort has begun to increase ${ }^{\mathrm{i}}$ (Council on Higher Education, 2010; Department of Education, 2005), South Africa still faces the issue of worryingly low completion rates amongst university students ${ }^{\mathrm{ii}}$ (Council on Higher Education, 2010; Motlanthe, 2010).

It is against this backdrop that the systemic and rapid utilization of technology within teaching and learning began to emerge (Jansen, 2003; Paterson, 2004). The idea that technology could drive some form of transformation quickly gained prominence in South African national policy documents, such as The National Plan for Higher Education (Department of Education, 2001), The National Research and Development Strategy (Department of Arts Culture Science and Technology, 2002), the National Research and Technology Foresight ICT Report (Department of Science and Technology, 2000), and the White Paper on e-Education (Department of Education, 2003), all of which assume that ICTs are central to improving education. These documents argue that using ICTs will add value to education, improve teaching and learning, encourage innovation, and contribute to transformation.

Higher education has an additional pressure in terms of its use of ICTs as it is seen as central to developing an information society. The renowned sociologist Manuel Castells locates higher education as the "engine of development in the new knowledge economy" (Council for Higher Education Transformation 2006, p. 3). This position has been reiterated in terms of African development by Kofi Annan (Bloom, Canning, \& Chan, 2006) and in South Africa's National Plan for Higher Education, which states that the sector has "a critical and central role to play in contributing to the 
development of an information society in South Africa both in terms of skills development and research" (Department of Education, 2001, p. 5).

However, the view that ICTs are great equalizers has receded as local realities and complexities of implementing ICTs in education in a diverse and divided terrain have become more evident (Czerniewicz, Ravjee, \& Mlitwa, 2007). ICTs form only one thread in a complex net of issues, and their use is dependent both on the broader socio-economic and political contexts, and on the local struggles and strategies around the distribution of resources and other aspects of redressing historical inequity (Ravjee, 2007).

A very pertinent issue facing South Africa and other developing countries is how we ensure that by using ICTs in teaching and learning we don't further disadvantage already disadvantaged students and yet still provide them with opportunities to participate in global, intellectual communities. As Broekman, Enslin, and Pendlebury (2002) remark "We do not wish to discriminate against students with less capacity - nor those with more capacity - to benefit or not to benefit from ICTs in the higher education sector" (p. 34).

Consequently, in the rapidly-changing environment of South African higher education, there is a lack of clarity about ICTs at four levels:

1. The significance ICTs have to students as an educational good or commodity.

2. How the global understanding of the information society or knowledge economy relates to South African higher education students.

3. Whether the use of ICTs is equipping students to be successful participants in the post-university world.

4. Whether ICTs in higher education are perpetuating existing divides amongst students.

In this research, I use Critical Discourse Analysis (CDA) as the mode of analysis, to understand more about the social relationships and identities students maintain in terms of ICTs. The specific concepts that inform this study include Gee's (2005) notion of $\mathrm{D}(\mathrm{d})$ iscourses as a means of explaining a social group's way of being in the world, its "form of life", its very identity as well as his conceptualization of grand societal "Big C" Conversations (Gee, 2005). I use Fairclough's three-level framework (Fairclough, 2001) to situate the texts within the socio-historical conditions and context that govern their process.

While discussion about meanings and identities is illuminating in helping universities to better understand their students' ICT behaviors, it also has specific relevance because it influences the way students use ICTs for learning. As Goode notes, the type of technological identity a student holds creates both academic opportunity and obstacles for him or her (Goode, 2010). I draw on Foucault's understanding of power as a choice under constraint to examine how students are empowered or disempowered through their Discourses about ICTs (Foucault, 1994a).

\section{Background to Research}

The idea that technology could drive some form of transformation in South African education began to gain prominence in the late 1990s. In 2001, the "Strategy for ICTs in Education" laid what was called "the basis for an ICT revolution in our schools" (Department of Education and Department of Communication, 2001, p. 28). The Strategy noted that the education system was "severely stratified and dependent 
on personal wealth" (p. 9) and if "ICT is a solution looking for a problem to solve", then education and training have many that beg attention (p. 9).

However, despite this willpower and the good intentions behind these strategies, computer penetration in schools has been remarkably slow. Current data from the National Education Infrastructure Management Systems shows that with $67 \%$ of schools with no computers for teaching and learning (Department of Education, 2007) and $77 \%$ without a computer centre, this will be impossible to realize (Department of Basic Education, 2009). In addition, even where infrastructure exists, skills shortages amongst teachers have in some cases resulted in laboratories being vastly underutilized (Hlatshwayo, 2008).

What does this mean in terms of ICT literacy? Well, a significant proportion of South African students arrive at university without having had direct experience of using ICTs at school. Even amongst those with some exposure, the degree to which they have acquired ICT literacy varies. In 2007, $18 \%$ of students had less than two years' experience using a computer when they entered university (Brown \& Czerniewicz, 2010). Only $42 \%$ stated they had learnt to use a computer through their school. This inequality of access is particularly pertinent for students from low socioeconomic groups who speak English as a second language (Czerniewicz \& Brown, 2009). Czerniewicz and Brown note that "Sixty three per cent of students from low socio-economic backgrounds indicated that they had below-average ease and adequacy of access to computers off campus, compared to $49 \%$ of students from high socio-economic backgrounds" (Czerniewicz \& Brown, 2009, p. 66).

Students who spoke English as a first home language had much more access to a computer off campus than those who spoke English as a second language; $31 \%$ of English second language speakers had no access to a computer off campus compared to only $10 \%$ of English first language speakers. (p. 66)

This pattern had flow-on effects with students in these demographic groupings, also being less confident in terms of their computer ability and having access to fewer supportive social structures in terms of using ICTs at university (Czerniewicz \& Brown, 2009b). This is not unique to South Africa as findings from elsewhere show that amongst youth globally, access is concentrated in the middle/high socio-economic groups (World Bank, 2007) and that people who suffer social disadvantage are much more likely to be disengaged from ICTs than the socially advantaged (Helsper, 2008).

Brown \& Czerniewicz (2010) have noted how within South Africa, this has resulted in a group of students entering university who are "outsiders to the digital world as it is commonly conceptualized and have termed the group 'digital strangers'" (2010, p. 363). They note how these mirror existing lines of social inclusion as this group is comprised more of women from low socio-economic groups who speak a South African language of African origin as their home language, and how this group of students are conscious of their outsider status. They caution against uncritical adoption of the concept as espoused by Prensky of young students as "digital natives" (Czerniewicz \& Brown, 2010,) noting that in the South African context, these types of technologically immersed and savvy youth are in the minority and represent an elite rather than a majority. 


\section{Critical Discourse Analysis as a Theoretical Perspective}

This research adopts a critical theory epistemology in order to understand how South African students construct the meaning about the role of ICTs in their lives. I draw on Critical Discourse Analysis (CDA) as a theoretical and analytical device to examine South African students' language about technology, its meaning, and its purpose and use in education.

CDA has been noted by Ainsworth and Hardy (2004) as being "regularly used to study identity" (p. 225). For Gee, big 'D' Discourses are a sort of identity kit. They are the combination of what people say, do, think, feel and value. Each community or social group masters a home-based discourse that integrates words, actions, values, feelings, attitudes and thinking in specific and distinctive ways. Each of these discourses is connected to a particular social group's way of being in the world, its "form of life", its' very identity it regards itself as having (Gee, 1996). Discourses are acquired through enculturation into a social practice and they cannot be taught (Gee, 1996).

Each discourse incorporates a usually taken-for-granted and tacit theory of what counts as a normal person and the right way to think, feel and behave. These theories crucially involve viewpoints on the distribution of social goods, like status and worth and material goods in society (who should and should not have them). They are defined not just by what they are but by what they are not (i.e., often in relation to an opposing discourse).

Discourse theories are related to the distribution of social power and hierarchical structure in society and empower the groups who have the least conflict between their discourses. Sometimes people's discourses can be conflicting. For example, a discourse can be at odds with a person's other social practices. Gee (2005) also notes that it is a great advantage when secondary discourses are compatible in words, deeds and values with one's primary discourse.

Goode (2010) looks at how holding a particular technological identity impacts the academic and social life of college students. Even in the US, she comments that there are rarely explicit technology prerequisites for college entrance, resulting in a range of literacy and experience: too often female, low income students of colour being the most under-prepared for the digital college environment. Focusing on how technology uniquely shapes the way individuals live their lives, Goode uses identity as a theoretical and methodological guide. Goode considers how experiences lead to the construction of a technological identity and examines how holding or not holding a technological identity impacts on an individual's ongoing endeavours. She comments on Wenger's view of identity as "a way of being in the world" and Gee's as acting and interacting as a "certain kind of person"(Goode, 2010, p. 5). Gee's affinity group is rather like Wenger's communities of practice. Viewing identities as a product of participation in communities (i.e., as contextually specific) can strengthen our investigation of how computing experiences influence an individual's relationships with technology (Goode, 2010).

However, identity construction is more than the sum of an individual's social experiences. There is an inherent tension between group affiliation and individual agency. Membership of an identity group does not determine behaviour but, as Foucault notes (Foucault, 1994b), there is an ease with which people readily accept the social groupings imposed on us. In trying to understand my research problem through a CDA lens I have found two researchers particularly useful, namely Norman Fairclough and James Paul Gee. 
James Paul Gee's work arises from what he calls an "American nonHallidayian model of grammatical and textual analysis" (Gee, 2004, p. 20). It has been largely situated in the movement of New Literacy Studies (NLS) which is based around the "idea that reading, writing and meaning are always situated within specific social practices within specific discourses (Discourses)" (Gee, 1999, p. 8). Operating from this educational context, Gee's work has focused on language and literacy acquisition as a form of socialization both for in schools (1994) and, more recently, in terms of literacy, learning and gaming (2003). His premise is that literacy in and of itself leads to no higher order, global cognitive skills (Gee, 1994), but that literacy acquisition is a form of socialization into a mainstream way of taking meanings, of making sense of experiences and that as students participate in different literacy practices, they begin to partake of this set of values and norms, of this world view.

Fairclough approaches CDA from a background of Hallidayian Systematic Functional Linguistics, whose linguistic characteristics he utilizes for analyzing the relations between discourse and social meanings (Blommaert, 2005). Fairclough's (1995, 2001) early models of CDA consisted of three inter-related processes of analysis tied to three dimensions of discourse. The three dimensions of discourse are the object of analysis (text), the process by which the object is reproduced (practice) and the socio-historical conditions which govern this process. Each of these dimensions requires a different type of analysis, namely "description of the text, interpretation of the relationship between text and interaction and explanation of the relationship between interaction and social context" (1995, p. 91).

As Gee (2004) notes, the linguistic bases of their two approaches, while different, are not incompatible and more recently, the two theorists have not been regarded as mutually exclusive. Rogers combines Fairclough's definitions of genre, discourse and style and Gee's situated identities and concept of boundary crossing (Rogers, 2004) to present a systematic study of these relationships and ways of being of low literate adults in Missouri. In the same book, two other authors also use combinations of Gee and Fairclough's approaches, thus demonstrating the synergy between the two and the way that it enabled them to obtain a different angle or perspective on the research in question (Gee 1996, 2005; Fairclough 1995, 2001).

Critical analyses, in its endeavour to uncover power relations, often focus on disempowered groups. However, I have taken the perspective, as also highlighted by Kvasny, Sawyer, and Purao (2004), that examining the phenomenon from the perspective of pre-constructed categories is a less useful position to take than examining human agency in terms of adoption and use of ICTs within the structural constraints of the social historical and cultural context that surrounds. As highlighted earlier, it is important as a critical discourse analyst to foreground one's conceptual tools. The four key concepts that are central analytical concepts in this research are meaning, identity, power and context.

Why these particular analytical concepts? Avgerou and Madon (2004) note, we need an understanding of new technologies (i.e., the Internet and the mobile phone) that can only be achieved by taking into account their symbolic meaning in everyday life. One of the ways of examining meaning is to look at identity, as identity also acts as a source of meaning and experience for people (Koc, 2006). It is not just about how the technology is adopted but about the way it is integrated into people's lives (Cushman \& McLean, 2008). However, critical research involves a shift away from just individual's situations and local meanings to the system of relations which make these meanings possible (Trauth \& Howcroft, 2006). Thus, context is critical if 
we are to understand how ICTs are used, especially in developing countries (Avgerou \& Madon, 2004).

Issues of power surface when people's freedom to set and pursue their own goals and interests (Zheng \& Walsham, 2008) or achieve their personally-constructed life projects (Cushman \& McLean, 2008) are curtailed. That is, where local actors are not able to shape ICTs to their interests and appropriate their functionality. Foucault views power as something exercised over those who are in a position to choose, although power influences what those choices will be.

Foucault separates the concept of power and domination (1994a, 1994b). On the one hand, he views power as a strategic game between liberties, where people can engage in the exercise of power on their own account, that is, the element of choice. On the other hand, domination is where the person has little room to manoeuvre because the margin of their liberty is extremely limited. The distinction between power and domination allows Foucault to condemn domination but not power. This is quite different to the previous critical view of power (Foucault 1994a, 1994b).

This view of power has enabled researchers to examine power at both a macro and micro level and to still view the individual as having agency. Agency is an important concept in this view of power and, while it can be an entire construct on its own, I have chosen to view agency within the construct of power. Thus, identity and meaning are essential in understanding how new technologies are appropriated; context is necessary to examine the system as a whole; and issues of power surface, as they influence what is possible within the context the actors operate within.

\section{Methodology}

The motivation for this research arose from research on South African university students' access to and use of ICTs for learning at university. The "Access and Use" project came about through the need to collect baseline data on what access university students really had to ICTs (in a highly multi-faceted sense) and what use (or non-use) they were making of ICTs for learning purposes (Czerniewicz \& Brown, 2006). In this project, students' attitudes towards ICTs were overwhelmingly positive, with quantitative data showing that students thought ICTs were essential for education and a positive benefit to their learning (Czerniewicz \& Brown, 2009). A link between positive disposition and above-average use of ICTs for learning led the authors to conclude that positive attitudes were an enabler in the take up of ICTs for e-learning (Brown \& Czerniewicz, 2007; Czerniewicz \& Brown, 2009). However, in a society such as South Africa with its legacy of apartheid (Department of Higher Education and Training, 2010) and with a growing and increasingly diverse student body (Cooper \& Subotzky, 2001) within a higher education sector only recently restructured towards transformation (Department of Education, 2001; Gillard, 2004) and operating for the most part under significant resources constraints (Council on Higher Education, 2004; Steyn \& de Villiers, 2007), it seemed to me curious that students' attitudes could be so similar and so positive.

As a researcher on this project, I became aware that within the timeframe of the project, we just could not do justice to the richness of the qualitative components of the survey. Responses to the open-ended questions were high (88\% of students answered at least one question) and provide an extensive corpus of texts. While CDA is more frequently used in the analysis of formal texts like policy documents, there has been a more recent move to using and encouraging CDA in new emerging texts and discourses (Luke \& Dooley, 2011). As van Dijk (1997) notes, as long as the texts yield insight into the crucial relationship between discourse and social power, then the 
use of CDA as an approach is valid. The data for this research is drawn from openended questions from a survey of students' access to and use of ICTs carried in 2007 amongst 3,533 students from six universities ${ }^{\text {iii }}$ across South Africa (located in four provinces).

Drawing on this type of data has also given me an added advantage of a large corpus of texts. This has been one of the more recent recommendations for CDA research, as Orpin (2005) notes explicitly that CDA has been criticized for its qualitative approach tending to be fragmentary and exemplified with data that is often not representative. By drawing on a large body of data, I am able to make more reliable generalizations and connect the qualitative findings back to the quantitative data from the survey.

I draw on Gee's understanding of $\mathrm{D}(\mathrm{d})$ iscourse. Little d Discourses refer to individual texts - language in use, in this study, the written responses of a person to the open-ended questions from a survey. Big D Discourses refer to identity; not individual identity but group identity - a way that an individual thinks, speaks and acts that is recognised by others in relation to the social world. I do not use discourses to mean the way people speak or the ideas of ideologies that people draw on. For this, I refer to what Gee's (2005) terms "Big C" Conversations, which aim to uncover "themes, debates or motifs that have been the focus of much talk and writing in some social group with which we are familiar or in our society as a whole" (p. 21). Gee further notes that most of us are aware of "societal Conversations going on around us like abortion, creationism, global warming, terrorism" (p. 29). Like Gee, I use Conversation explicitly as a tool of inquiry to examine what Conversations a piece of text refers to and what it does not.

I utilized Fairclough's dimensions of discourse as an analytical guide to move between the text, discursive level and social practice (1995). My analysis begins at the textual level where I undertake linguistic analysis of components that are evident in the genre of text, drawing on Fairclough and the way he understands linguistic features that elucidate agency and modality, as well as questions from Gee's analytical process that relate directly to context, situated meaning, power and identities. At the discursive level, I inspected the external Conversations which were evident and then examined the relationship between text and interaction at the level of social practice to determine how students' technological identities were constructed.

\section{Analytical process}

To start with, I sorted the responses to the open ended questions in terms of word frequency and began working through the responses in order of most discursive (i.e., greatest number of words) to least discursive (least number of words). I began the analysis by identifying Conversations within the text using a semi-grounded approach. I drew on research on discourses of ICTs which had revealed a variety of themes.

While terminology differed between contexts (whether the ICT discourses are viewed in relation to policy, education, government, etc.), the themes that were common in the literature across all settings were ones of technological optimism, efficiency, liberation, imperialism/globalization (digital divide) and productivity (Budd, 2005; Roode, Speight, Pollock, \& Webber, 2004; Thompson, 2004; Wilson, 2003). With this sense of potential Conversations, I selected a small random group of texts and read through them identifying recurrent themes. I then sorted the texts according to the initial categorization and read through my first level coding as a group, adjusting and refining the categories until a consistent theme began to emerge. 
I expanded my corpus (having learnt from the initial process that it was usually pointless reading "bits of text" less than 17 words in length). I applied my coding constructs to the expanded text and continued coding in this way. In terms of the nature of the CDA, the students who completed more of the open-ended questions tended to provide better data for analysis (although there were some students who only answered one open-ended question but provided quite lengthy, insightful texts). So the majority of my sample is drawn from students who made a larger contribution to the open-ended data within the survey. The final sample comprised of 840 students' texts.

This process was an iterative one as while reading through the texts, I refined the definition and description of the various themes which would then involve a reiterative process of coding. What emerged from the data were 6 themes or "views" of technology. I then worked with a subset of the texts from within each theme and sought to unpack what I could find about how students viewed their ICT identity through the texts (Gee, 2005).

Within each theme, I analysed the text, as per Fairclough's dimensions of Discourse. I started by providing demographic information connected to the student both as context and because Gee (1996) also connects Discourses to a particular social group's way of being in the world, their very identity. At the micro level, I examined the content contained in the text. At the discursive level, I begin to look outside the text at what connections are made to other Conversations outside the current situation. In order to contextualize what is "inside" and what is "outside" the text, I examined the larger or main activity that participants were engaging in. At the level of social practice, I drew on the questions (outlined in Table 1) as well as analysis of agency and modality at the level of the text, to explain students' situated meaning, context, distribution of social goods (power) and identities. I sought to unpack what this told me about how students think, feel, value and use ICTs for their learning, as per Lankshear and Knobel's (2007) use of Gee, and describe what I could tell about how students (who were operating from within a particular discourse) viewed the world.

Having identified six themes in the data and analysed them in order to reveal something about an individual's actions, thoughts, feelings and values, I began to highlight the key characteristics within each theme and went back to the larger corpus of text to demonstrate how these were not only individual concerns but ways of thinking about ICTs that are common to a larger group.

Table 1

Selection of Focusing Questions Relevant to the Study Drawn from Gee (2005)

\section{Gee's building tasks and related focusing questions ${ }^{\text {iv }}$}

\section{Context}

What is the larger or main activity going on in the situation? [Q6]

What sorts of social relationships seem to be relevant to, taken for granted in, or under construction in the situation? [Q12]

What sorts of connections are made to previous or future interactions, to other people, ideas, texts, things, institutions, and Discourses outside the current situation - inter textuality? [Q19]

\section{Situated meaning}

What is the situated meaning of some of the words and phrases that seem important to the situation? [Q1]

I-Statement and modality




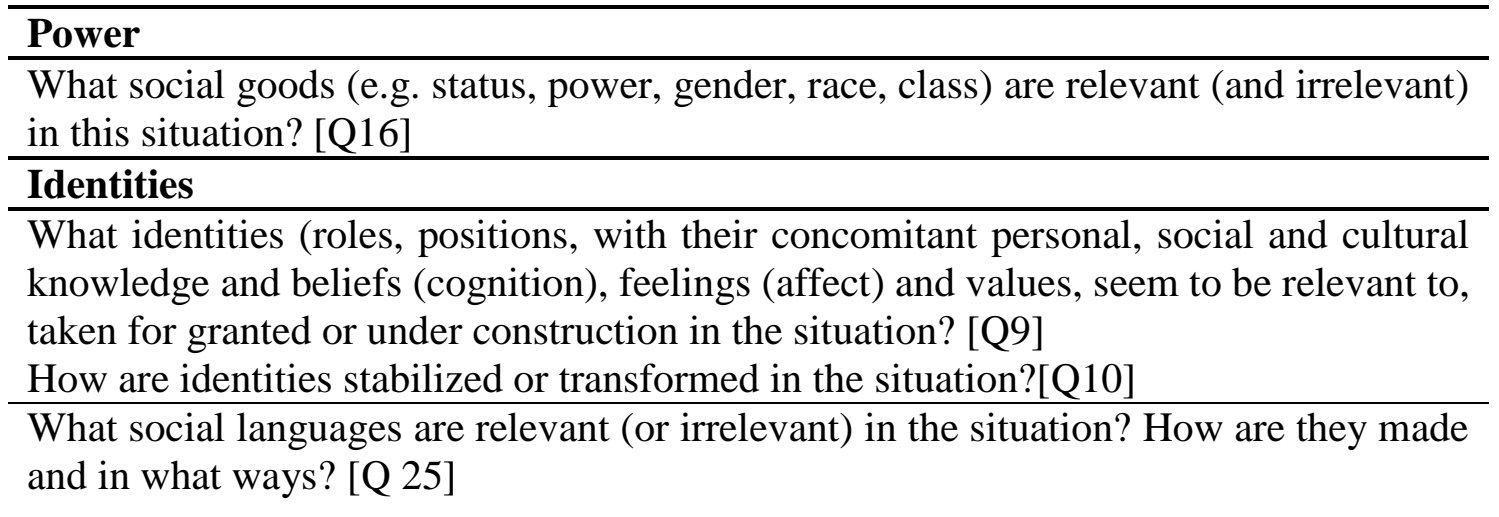

\section{Discourses}

In this research six Discourse groups were evident within the texts of South African higher education students. In describing these I draw on the common themes using students' direct quotes to illustrate the meanings. Respondents' anonymous identification is provided after each quote with square brackets. The dominant Discourse was one of Globalization, with 34\% (370) of students in the sample drawing on this Discourse in some respect. Common elements are global opportunity, global citizenship, the information society and notions of the digital divide, having and not having access, and disadvantage. Overall, this Discourse is differentiated from others by the strong association with disadvantage and the view of global opportunity generically (whether it be information, learning, communication or future prospects). Specifically, students refer to the opportunities ICT affords them in terms of furthering themselves in their studies, e.g. finding bursaries and scholarships "even when we check for bursaries, scholarship, job opportunities, job for degree it easy to get them" [969] and in the job market "because every job requires a person to be computer literate, e.g. a person who will be able to type, do presentation on conferences using personal laptops" [3272].

Students' texts within this Discourse also describe many types of disadvantage. For some students, the disadvantage in relation to using ICTs is related to their past background. For example different opportunities that exist at the level of the schools' system in South Africa is an issue of which university students are very conscious: "I wish access would be made to learners from disadvantaged schools, because some of us are only exposed to ICTs here at university" [1161].

For others, disadvantage is represented by cost of access. While the lack of money is a feature of their lives today, for many the reason accessing ICTs costs them more is because of past background, that is, they live far away from university: "I have to travel for 30 kilometers and pay ten rands for the taxi fare and after that I still have to pay 10 rands for 30 minutes using the internet" [877].

There are also indirect references to apartheid which one can see emerging in statements where students refer to demographics: "I wish for greater information about developments in the field of ICTs to be made to more people (vary the demographic)" [2252].

However, the discrimination students feel they face is not only in relation to the country's past history; it continues today. Students who rely on campus access at all times of the day and night are made to feel like criminals: "I suggest security personal in $\mathrm{xx}$ campus better stop looking around us when using computer labs, because we are not thiefs, crooks or thugs but here to learn and need to be given chance to explore the net/internet" [279]. Universities also prioritize ICT access 
according to what students are studying and so those who are not doing the elite courses also feel discriminated against: "It's a horrible situation under which we are studying/ seldom access internet in the library or medical library. $\mathrm{i}$ am always chased out in medical library cos i am not a med student" [359]

A learning Discourse is the next most dominant Discourse, with $29 \%$ (315) of students identifying with ICTs in this kind of way. The key element is ICTs taking on a strong imperative in terms of learning. Common elements include references to learning or studying activities in terms of their efficiency and effectiveness. This Discourse is differentiated from other Discourses by its emphasis on learning and not just productivity generally.

Many students regard ICTs as having a positive effect on their learning. From the extent of believing that using ICTs gets you better marks, to more astute and carefully reflective comments that demonstrate students' awareness of how it helps them learn. Clearly, for some students, the medium makes the process of studying more pleasant: "I am more likely to remember information from ICTs than from studying from a textbook" [2535], and "makes me enjoy doing my assignments \& projects \& helps me achieve better marks for my courses" [35]. Some students even ascribe the personal capacity to technology "ICT is like a personal tutor/mentor because you can get clarity an almost everything you need" [968].

Pedagogically, some interesting benefits emerged from students within this theme. Students report that using ICTs makes it easier for them to take notes about lectures: "lecture notes made available enables us to pay more attention and enables us to write down lecturers explanations and additional notes" [2591].

For many of the students, there is a positive enjoyment factor to using technology: "makes me enjoy doing my assignments \& projects \& helps me achieve better marks for my courses/ it makes studying enjoyable \& easier" [34], and "it's extremely fun to use ICTs they make school learning fun \& just provide exciting challenges in life for human" [169].

Discourses of globalization and learning account for almost two thirds of the students' perceptions of ICTs (63\%). The deterministic Discourse is evident amongst $15 \%$ or 162 students. The common themes that emerge are a strong, dominant (almost uncritical) view of technology as being essential, and, by association, the skills to use ICTs as being more highly valued and necessary than other skills.

The high prioritization of technology is evident throughout this theme with students calling for it to be compulsory: "I think ICTs should be a compulsory course because nowadays wherever a person is working, a computer is needed" [2494]. One student even refers to the privilege of access as being a debt they owe: "We have the privilege of having access to and using these new technologies, which are very helpful to us. our greatest debt, which it is a joy to acknowledge is to those who put this system in place for this university" [2634].

Within this theme, students perceive the ability to use technology not only as better but that people who use technology are better and smarter than those that do not, as this student indicates: "I would if it were possible ask to be taught firstly some basics that will lead me into knowing computer as i know myself" [88]. Having an ICT ability/aptitude advances students while a lack of ability disadvantages them. "Actually, I don't know because I am not well versed with the system. I think by being orientated in the ICT field, I can be able to use it and be part of the beneficiaries of the system" [2679].

Discourses of liberation were evident amongst 12\% (138) of students and involve a view of the use of ICTs primarily as a means of acquiring information and 
its advantageous effects. It has a strong positive association with knowledge with a lesser awareness of the need to approach information with caution.

An example of uncritical information seeking practices that are nevertheless empowering for students is how Google is used: "I think it's good. It is good. Because if you don't understand a question, you can ask the Google. And Google will research for you. And if you don't understand the textbook, you can learn it online"; and "it gives you info from around the world as well as how trustworthy and old they are, and who compiled them" [372].

However, while for some students this is empowering, for others it is constraining and they find the vastness of information has a negative impact on their learning: "The sites with information tend to contradict each other, and that confuses me" [1875], and "I honestly want to trust ICTs and I hope that people should stop putting rubbish in them. I just only wish that facts could be reliable" [2113].

The direct and indirect links to knowledge are often in relation to expansion of the curriculum and the opportunity to get knowledge without teaching: "A vast array of information [is] available on the internet. They are an essential tool, that will provide value to whatever course(s) one is doing. They are the way forward [of the future]" [2584]. Further, "if everybody would have an access to use ICTs it would be easy to get knowledge without being taught skills and abilities et cetera" [775].

Still evident within the corpus, although less frequently, were the two Discourses I have termed productivity Discourses and disembodied Discourses. The former accounts for $8 \%$ of the sample (90 students) and holds a view that technology makes life easier, reduces workload and stress. The common theme of the productivity Discourse is the view that ICTs are central to personal productivity or non productivity. For example "save time, makes work easier, communication faster" [2048]; making things easier "it makes life easy and things go smoothly than you expected" [419]; or the opposite "can be time consuming if you lack self discipline. not good health wise" [1072].

The disembodied Discourse only accounts for $2 \%$ (or 21 ) of students within the sample. This is a view of ICTs as a space that is lacking in physical presence. It is generally expressed as making students feel disconnected from the lecturer and other tangible physical forms, such as pen and paper and books. For example, "a person can depend too much on using ICTs and not even use their own mind to think and study from books" [216].

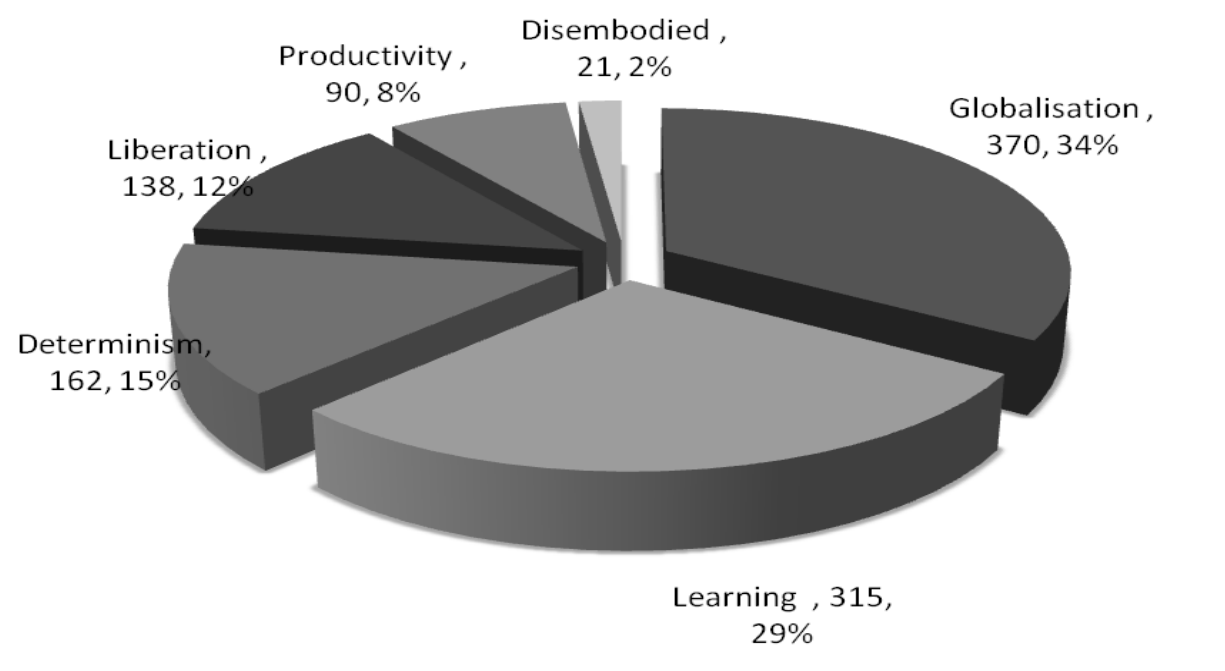

Figure 2. Frequencies and percentage of Discourse types ${ }^{\mathrm{v}}$. 
There are of course some similarities between the Discourses. For example while there is some overlap in ideas between Discourse of globalization and liberation, as information available via the Internet is inherently global in nature, the difference is that students who exhibit a globalization Discourse do not foreground access to information - they foreground the opportunity to be globally connected. Students who exhibit a liberation Discourse foreground the link between information and knowledge, and whether this is local, national or global is irrelevant to them.

The efficiency aspect of the learning Discourse and the efficiency aspect of the productivity Discourse are also similar in that they make tasks easier for an individual. However, the nature of the tasks which are fore-grounded are different. In the learning Discourse, the tasks and activities in which the students engage are directly related to learning or studying activities; whereas in the Productivity Discourse, the tasks are generic and relate to a broader more all-encompassing purpose not just limited to the university.

It is also interesting to note that a quarter of the sample (221 students) had mixtures of more than one Discourse in their texts. It is important to note I do not view identities as static or necessarily singular and that there are often tensions between students' multiple Discourses.

The Discourses of globalization and learning are not surprisingly the two that most frequently occur together, as they are also the most dominant Discourses within the sample. The association of the two indicates that some students are caught between valuing the opportunities that technology has for learning and the difficulties associated with access. For example, a female student describes the complexities of access and the cost in terms of time. She favours, but is strongly aware of, the specific learning benefits she derives from technology when she is able to keep up to date and ahead of her studies, and engage more confidently with her lecturer. "The use of sites like DTI and the news at SABC 3 and labour.net.com, help me keep ahead on my studies. I am able to read ahead, and sometimes challenge my lecturers on subject matters that I read about. My institution was not being helpful at all as far as ICTs are concerned, there is poor system support personnel" [3093].

There are also some interesting contradictions within the mixed Discourses that suggest these might be in a state of flux for students. For example, students who have a deterministic Discourse and therefore an almost blind acceptance of the need for ICTs at university are tentatively beginning to become aware of their learning benefit.

\section{Meanings: Migrants into Digital Worlds}

Having made a case for the consideration of the six themes identified above as group identities, this then led me to the question of whether these different social meanings of technology constituted a common Discourse identity amongst students. Like Norton, I argue that each Discourse is not just a collection of ideas but a representation of an identity: It shows how students understand their relationship to the world; how that relationship is constructed across time and space; and, how they understand the possibilities for the future (Norton, 2000).

Both Norton and Gee position identity in relation to a desire for recognition and affiliation, with Gee observing that "social practices set up roles or positions within which people become 'insiders', 'outsiders' or 'marginal' with respect to the social groups whose practices these are" (Gee, 2004, p. 32). Norton points out that desire is inseparable from material resources in society, where those with access to those resources are accorded access to power and privilege (Norton, 2000, p. 42). 
As per the critical approach, I am primarily interested in the technological identities of the students who see themselves as outsiders or marginalized. The students within a globalization Discourse and deterministic Discourse are most alienated, but the way they deal with or approach this alienation occurs in different ways. In conceptualizing my research for the "Mobility Language Literacy" conference held in Cape Town in January 2011, I was inspired toward a metaphor with which to capture these nuanced differences in approaches. Amongst the group of students who perceived themselves as "outsiders" to the digital world, I determined three types of approaches: the alien, the escapee, and the converted.

The Alien represents students hovering on the outskirts, feeling excluded; they may cross over for short periods of time and then head back home to the familiar. The person who feels like an alien needs someone to draw them in. With the little sense of agency they have, given their "I'm not good enough" sense of the digital world, they are unlikely to take up opportunities that are presented. It is here the Conversations around globalization and the information society have a negative impact on individuals.

The Escapee represents students desperate to get away from the confinements of where they have been to seek better opportunities. These have a conscious acknowledgement of being an outsider but a desire to change and become assimilated and therefore seen as indigenous. For this group, the information society has tantalized them with a sense of possibility. The escapee is an outsider but keen to be an insider and to make the most of opportunities. The escapee makes a conscious decision to leave the old behind and to be proactive in acquiring the new. This is perhaps one's ideal type of student in that they are eager to learn, yet aware of their limitations.

The Converted represents students who don the new cloak of technology and hope everyone sees them as an indigenous person while figuring all of it out as they go along. One of the less obvious identity strategies to recognize is the converted, as they are trying to hide amongst the population. They are in disguise (and perhaps even in denial) which means they will not admit to problems, nor take up voluntary opportunities for migrants, and they hang with the gang; hoping their disguise will not be discovered. It is likely that these students report a high self-efficacy and confidence with regards to technology use because that is what they feel but we need to be conscious that this does not necessarily equate to their actual knowledge and ability.

Focusing on this group of marginalized students (migrants to the digital world), we see that students with different Discourse identities approach this migration differently. The external Conversations of globalization and the information society have a role in both facilitating and constraining their participation and future opportunities. As Foucault notes, membership of an identity group does not determine one's behaviour (Foucault, 1994b) but there is an ease with which people readily accept the social groupings imposed on them. Many students do not exercise individual agency and just go with the flow but still feel outsiders, marginalized, excluded, lost, and powerless.

\section{Conclusion}

Public rhetoric that ICTs are inevitable and essential for education is reiterated by students who demonstrate positive attitudes towards ICTs. Corresponding data from the literature that ICTs are being used voluntarily legitimizes the use of technology in education as policy makers look for "proof" to show ICT's acceptance by its users. 
However, the range of Discourses uncovered in this study show that students' Discourses about ICTs are complex, often multiple, and contradictory. While access is a multifaceted issue, the focus in this research is students' personal access to technology, that is, their motivations, values, purposes, and beliefs. By excavating below the surface I have demonstrated that there is deep inequality at the level of personal access. In addition, the use of ICTs in education is reinforcing power, domination and interests of certain groups of students at the expense of others.

Students have very real problems and inadequacies with regard to using ICTs for their learning. Asking them if it is something they want to do is a bit like asking them whether they want their degree in English or isiXhosa. Few are going to say isiXhosa because it is not the language of power. Students come to university to equip themselves to get a good job and students want to do what is most likely to make them most employable. They perceive using ICTs as giving them power, the edge over others. It is a commodity that is tradable, that is, ICT skills convert to greater economic potential.

While I have noted the dialectical relationship between Discourses and technology earlier it is important to foreground that students' Discourses are not singular. In fact they can be multiple and contradictory and may even cause conflict if as Gee notes there are contradictions between students' primary and secondary Discourses. In addition students' Discourses can and do open up various possibilities and options in terms of their use of technology which in turn has the potential to transform that student's Discourse. So my view of Discourses is that they are a multifaceted, relational, and transformable concept not a static, one dimensional one.

Students are right in the fact that the ICTs are necessary and valued in the world of work; so it is pointless to persuade them otherwise, and would be a folly to try. While I agree with Broekman et al. in their notion of the "dilemma of social justice" (Broekman et al., 2002), I do not believe we ought to give students a choice as to whether or not to engage with ICTs but ought to assist students with different strategies as to how to engage with ICTs.

This study was conducted in 2007 before the huge rise in social software and at a time when some of the institutions in which the students were located had just merged or were only starting to explore policy and structures related to e-learning. However, while there is no doubt that students' use of technology is changing rapidly, as mentioned in the background, the South Africa' schooling system is not. Every year a small but constant number of students arrive at University never having personally used a computer before and this isn't changing (Nash, 2009). So the obvious question that emerges is how are Discourse identities similar or different in a different space and time and are any new Discourses emerging? It is still clear that Universities in South Africa need to continue to acknowledge that students will be entering university for some time yet as digital migrants.

At the university level, computer literacy training will not always work for the range of Discourse identities outlined in this research. Those who are responding to the migration into the world of ICTs as converted or aliens will not attend. If training is made compulsory, aliens are likely to fall behind as they do not see the purpose of what they are doing or their own potential to do it. The converted are likely to try and skip ahead because they think they are past it.

One solution might be to open up Information Literacy programs, which are in place perhaps for specific courses of groups of students, to a wider range of students. As DeJager and Nassimbeni (2005) note, librarians are increasingly moving towards assuming the responsibility for providing students with graduate skills and 
information skills, and faculties and educational technology departments need to capitalize on this

At a fundamental level, ICT use (for graduateness) needs to be embedded in the curriculum in a strategic way, that is, involving assessment but still in a way that gives students an element of choice according to their abilities/interests (Broekman et al., 2002). Training needs to happen within a context and needs to have a purpose. For example, it cannot be just "how to use Microsoft Word" but rather "how to easily format your assignment". The power is with academics and tutors, for students not to be ICT whizzes but to use ICTs appropriately for their discipline, that is, to make them contextually relevant for students.

The Health Sciences is one area where this appears to be happening (Czerniewicz \& Brown, 2007; Greenhalgh, 2006; Ward, Gordon, Field \& Lehmann, 2001). I would argue that it is necessary for every graduate to not just be able to personally use ICTs as a tool themselves (and that has been shown to be problematic as we do not even know what level of personal ICT literacy and competence we are equipping our graduates with in higher education) but also as solutions for their fields.

In order to do this, each field needs to be aware of and train their students in using ICTs as a way of empowering themselves and their professional and social communities. Use of ICTs needs to be embedded in the curriculum. This is not a new suggestion, as already in 2003 the South African government defined e-literacy (for the schools sector) as "more than developing computer literacy and the skills necessary to operate various types of information and communication technology" (Department of Education, 2003, section 2.3, p. 15).

This included the ability to "access, analyse, evaluate, integrate, present and communicate information", create knowledge and new information and to "function in a knowledge society by using appropriate technology and mastering communication and collaboration skills" (Department of Education, 2003, p. 15).

ICT literacy is not an isolated skill or need and should not be treated as such. It makes sense, given links between digital inclusion and social inclusion, that ICT literacy is tied up within other academic development issues. As boundaries between information literacy and other academic literacies become more porous, it is essential that librarians, educational technologies, and language development professionals work together to develop students' digital literacy within the context of their background and their current discipline.

Collective resources have also been noted as playing an important role in empowering and disempowering students in terms of their achievement at university. Through "linking" (building connections to people in positions of power who provide access to resources) students can draw on peer-to-peer networks that cross Discourse groups and seek support and encouragement.

Universities need to reconceptualize ICTs not as the answer but as part of the problem. Using ICTs is not going to miraculously address students' learning difficulties, although some of its uses do help students to produce better output, for example the ability of word processing packages to do spell checks and the Internet to provide definitions and explanations of concepts and words. However fundamentally, ICTs are not the answer to learning problems. We need to ignore the hype that ICTs are going to change the way we teach and the way we learn (all the hype that comes with first world notions of the digital native and Web 2.0) (Batson 2009; Prensky 2001a, 2001b). We need to work with students to ensure that, at the very least, we equip them to make technology work effectively at university and in their chosen careers. Then, we can use technology to our country's economic benefit. 


\section{References}

Ainsworth, S., \& Hardy, S. (2004). Critical discourse analysis and identity: Why bother? Critical Discourse Studies, 1(2), 225-235.

Avgerou, C., \& Madon, S. (2004). Framing IS studies: Understanding the social context of IS innovation. In C. Avgerou, C. Ciborra, \& F. Land (Eds.). The social study of information and communication technology (pp. 162-182). New York, NY: Oxford University Press.

Batson, T. (2009). Why is Web 2.0 Important to Higher Education? Retrieved September $\quad 14, \quad 2010, \quad$ from http://campustechnology.com/Articles/2009/04/15/Why-Web-2.0-isImportant-to-Higher-Education.aspx? $\mathrm{p}=1$.

Blommaert, J. (2005). Discourse: A critical introduction. London, UK: Cambridge University Press.

Bloom, D., Canning, D., \& Chan, K. (2006). Higher education and economic development in Africa, World Bank. Retrieved August 26, 2010, from http://www.arp.harvard.edu/AfricaHigherEducation/Reports/BloomAndCanni ng.pdf.

Broekman, I., Enslin, P., \& Pendlebury, S. (2002). Distributive justice and Information Communication Technologies in higher education in South Africa. South African Journal of Higher Education, 16(1), 29-35.

Brown, C., \& Czerniewicz, L. (2007). If we build it will they come? Investigating the relationship between students' access to and use of ICTs for learning. South African Journal of Higher Education, 21(6), 732-747.

Brown, C., \& Czerniewicz, L. (2010). Debunking the digital native: beyond digital apartheid, towards digital democracy. Journal of Computer Assisted Learning, 26(5), 357-369.

Budd, Y. (2005). Technological discourses in education. Proceedings of the International Conference on Critical Discourse Analysis: Theory into Research. Tasmania, AUS: University of Tasmania.

Cooper, D., \& Subotzky, G. (2001). The skewed revolution: Trends in South Africanhigher education: 1988-1998. Cape Town, Education Policy Unit, S.A.: University of Western Cape.

Council for Higher Education Transformation. (2006). An approach to developing higher education as a field of study in Africa. Retrieved July 25, 2012, from http://chet.org.za/papers/approach-developing-higher-education-field-studyafrica

Council on Higher Education (2004). South African higher education in the first decade of democracy, Retrieved July 25, 2012, from http://www.che.ac.za/documents/d000081/SA_HE_10years_Nov2004.pdf.

Council on Higher Education (2010). Access and throughput in South African Higher Education: Three case studies. Higher Education Monitor, 9, Retrieved July 25, 2012, from http://www.che.ac.za/documents/d000206/:

Cushman, M., \& McLean, R. (2008). Exclusion, inclusion and changing the face of information systems research. Information Technology \& People, 21(3), 213221.

Czerniewicz, L., \& Brown, C. (2009). A virtual wheel of fortune? Enablers and constraints of ICTs in higher education in South Africa. In S. Marshall, W. Kinuthia, \& W. Taylor, (Eds.), Bridging the knowledge divide: Educational technology for development (pp. 57-76). Colorado, USA: Information Age Publishing. 
Czerniewicz, L., \& Brown, C. (2010). Born into the digital age in the south of Africa: the reconfiguration of the "digital citizen". In L. Dirckinck-Holmfeld et al (Eds.), Proceedings of the 7th International Conference on Networked Learning 2010, (pp. 859-865).

Czerniewicz, L., \& Brown, C. (2006). The virtual Möbius strip. Retrieved January 31, 2011, from http://www.cet.uct.ac.za/virtualmobius.

Czerniewicz, L., Ravjee, N., \& Mlitwa, N. (2007). Information and Communication technologies (ICTs) and South African higher education: Mapping the landscape In T, Auf der Heyde et al (Eds). Review of Higher Education in South Africa: Selected Themes. Pretoria: Council for Higher Education.(pp. 53-76).

De Jager, K., \& Nassimbeni, M. (2005). Information literacy and quality assurance in South African higher education institutions. Libri, 55, 31-38.

Department of Arts Culture Science and Technology (2002). South Africa's national research and development (R\&D) strategy. Retrieved July 25, 2012, from http://www.info.gov.za/otherdocs/2002/rd_strat.pdf

Department of Basic Education (2009). Number of all the ordinary schools with or without a computer centre Retrieved August 28, 2010, from http://www.thutong.doe.gov.za/ResourceDownload.aspx?id=40215\&userid=8 $\underline{913}$

Department of Education (1999). Call to action: Mobilising citizens to build a South African education and training system for the 21st century. Pretoria, Government Printers. Retrieved November 2, 2010, from http://www.capegateway.gov.za/Text/2004/5/tirisanocalltoaction.pdf.

Department of Education (2001). The national plan on higher education. Pretoria, Government Printers. Retrieved November 2, 2010 from http://sun025.sun.ac.za/portal/page/portal/Administrative_Divisions/INB/Hom e/Documentation/Documentation_National/National\%20Plan\%20for\%20High er\%20Education\%20in\%20South\%20Africa.pdf

Department of Education (2003). White paper on e-education: transforming learning and teaching through ICT. Department of Education Pretoria. Pretoria, Government Printers. Retrieved June 1, 2006, from http://www.info.gov.za/whitepapers/2003/e-education.pdf.

Department of Education (2005). Student enrolment planning in public higher education. Pretoria, Department of Education. Retrieved August 26, 2010, from

http://www.dhet.gov.za/LinkClick.aspx?fileticket=HCdtc6KnvOs\%3d\&tabid= $\underline{417 \& \operatorname{mid}=1221}$

Department of Education (2007). National assessment report (public ordinary schools). Retrieved January 31, 2011 from http://www.info.gov.za/view/DownloadFileAction?id=77863.

Department of Education and Department of Communication (2001). A strategy for information and communication technology in education. Retrieved August 15, 2008 from http://www.info.gov.za/otherdocs/2001/ict_doe.pdf

Department of Higher Education and Training (2010). Keynote address by Minister of Higher Education and Training Dr Blade Nzimande to the Stakeholder Summit on Higher Education Transformation, Cape Peninsula University of Technology. Retrieved November 1, 2010, from http://www.info.gov.za/speech/DynamicAction?pageid=461\&sid=9506\&tid=9 523. 
Department of Science and Technology (2000). National Research and Technology Foresight ICT report. Pretoria, Government Printers, Retrieved August1, 2012, from

http://www.foresightfordevelopment.org/2/index.php?option=com_sobi2\&sob i2Task=sobi2Details\&catid\&sobi2Id=117\&Itemid\&font-size=larger

Fairclough, N. (1995). Critical discourse analysis: the critical study of language. Essex, UK: Longman.

Fairclough, N. (2001). Language and power (2nd ed.). London, UK: Longman.

Foucault, M. (1994a). The subject and power. In J. Faubion (Ed.), Michel Foucault: Power (pp. 326-348). New York, NY: The New Press.

Foucault, M. (1994b). Truth and power. In J. Faubion (Ed.), Michel Foucault: Power (pp. 111-133). New York, NY: The New Press.

Gee, J. P. (1994). Orality and literacy: From the savage mind to ways with words. In J. Maybin (Ed.), Language and literacy in social practice (pp. 39-60). Clevedon, UK: Shoty Run Press Ltd.

Gee, J. (1996). Social linguistics and literacies: Ideology in discourses. London, UK: Falmer Press.

Gee, J. P. (1999). The new literacy studies and the "social turn". Retrieved July 25, 2012, from http://www.schools.ash.org.au/litweb/page300.html.

Gee, J. P. (2004). What is critical about critical discourse analysis? In R. Rogers (Ed.), An introduction to critical discourse analysis (pp. 19-50). New Jersey, NY: Lawrence Erlbaum.

Gee, J. P. (2005). An introduction to discourse analysis. New York, NY: Routledge.

Gillard, E. (2004). Report on the colloquium on 10 years of democracy and higher education change, Council on Higher Education. Retrieved June 1, 2006, from http://www.che.ac.za/documents/d000085/GillardColloquiumReport4February2005.pdf.

Goode, J. (2010). The digital identity divide: how technology knowledge impacts college students. New media and society, 12(3), 1-17.

Greenhalgh, T. (2006). Computer assisted learning in undergraduate medical education. British Medical Journal, 322, 40-44.

Hlatshwayo, N. (2008). The readiness of teachers to integrate information and communication technology for learning in a selected school in the Gauteng Online project. Unpublished Masters in Education, University of Johannesberg. Retrieved July 25, 2012, from https://ujdigispace.uj.ac.za/handle/10210/901

Helsper, E. (2008). Digital inclusion: An analysis of social disadvantage and the information society. Retrieved January 31, 2011, from http://www.communities.gov.uk/documents/communities/pdf/digitalinclusiona nalysis.

Jansen, J. D. (2003). Changes and continuities in South Africa's higher education system, 1994 to 2004. In L. Chisholm (Ed.), Changing class? Education and social change in post-apartheid South Africa (pp. 293-314). Pretoria, South Africa: Human Sciences Research Council.

Koc, M. (2006). Cultural identity crisis in the age of globalisation and technology. The Turkish Online Journal of Educational Technology, 5(1), 37-43.

Kvasny, L., Sawyer, S., \& Purao, S. (2004). The digital divide and information systems research: Stepping up or stepping away? MISRC / CRITO Digital Divide Symposium, University of Minnesota . Minneapolis, MN: University of Minnesota. Retrieved on 1 August 2012 from http://purao.ist.psu.edu/confpapers/CRITO-Kvasny-Sawyer-Purao-2004.pdf 
Lankshear, C., \& Knobel, M. (2007). Researching new literacies: Web 2.0 practices and insider perspectives. E-Learning, 4(3), 224-240.

Luke, A., \& Dooley, K. (2011). Critical literacy and second language learning. In E. Hinkel (Ed.), Handbook of research in second language teaching and learning (Vol II), (pp. 856-866). London, UK: Routledge.

Motlanthe, K. (2010, 22 April). Address by the Deputy President, Kgalema Motlanthe, at a Higher Education Summit. Retrieved on 1 August 2012 from http://www.uj.ac.za/EN/AboutUJ/TransformationOffice/Documents/Deputy_P resident_HE_Summit.pdf

Norton, B. (2000). Identity and language learning: Gender, ethnicity and educational change. Harlow, UK: Pearson Education Limited.

Nash, (2009). Computer skills of first-year students at a South African University. Proceedings of the 2009 Annual Conference of the Southern African Computer Lecturers Association, Mpekweni, (pp. 88-92).

Orpin, D. (2005). Corpus linguistics and critical discourse analysis: Examining the ideology of sleaze. International Journal of Corpus Linguistics, 10(1), 37-61.

Paterson, A. (2005). Changing the landscape of learning: The impact of institutional mergers on blended learning provision in South African higher education. $\begin{array}{lllllll}\text { IJEDICT } & 1 & (2) & \text { retrieved July 25, 2012, from }\end{array}$ http://ijedict.dec.uwi.edu/viewarticle.php?id=48\&layout=html.

Prensky, M. (2001a). Digital natives, digital immigrants. On the Horizon, 9(5), 1-6.

Prensky, M. (2001b). Digital natives, Digital immigrants, Part 2: Do they really think differently? On the Horizon, 9(6), 1-9.

Ravjee, N. (2007). The politics of e-learning in South African higher education. International Journal of Education and Development using Information and Communication Technology, 3(4), 27-41.

Rogers, R. (2004). Literate identities across contexts. In R. Rogers (Ed.), An introduction to critical discourse analysis (pp. 51-78). New Jersey, NY: Lawrence Erlbaum

Roode, D., Speight, H., Pollock, M., \& Webber, R. (2004). It's not the digital divide it's the socio-techno divide! ECIS 2004 Proceedings. Paper 112. Retrieved on 1 August 2012 from http://aisel.aisnet.org/ecis2004/112

Steyn, A. G. W., \& de Villiers, A. P. (2007). Public funding of higher education in South Africa by means of Formulae. In T. aud der Heyde et al (Eds). Review of Higher Education in South Africa, Council for Higher Education. Pretoria: Council for Higher Education .(pp. 11-51). Retrieved July 25, 2012, from http://www.che.ac.za/documents/d000146/5-Review_HE_SA_2007.pdf.

Thompson, M. (2004). ICT, power, and developmental discourse: A critical view. Electronic Journal on Information Systems in Developing Countries, 20(4), 125.

Trauth, E., \& Howcroft, D. (2006). Social inclusion and the information systems field: Why now? In E. Trauth, D. Howcroft, T. Butler, B. Fitzgerald, \& J. D. Gross (Eds). Social inclusion: Societal and organisational implications for information systems (pp. 347-64). Boston, MA: Springer.

Van Dijk, T. (1997). Discourses as structure and process. London, UK: Sage.

Ward, J., Gordon, J., Field, M., \& Lehmann, H. (2001). Communication and Information technology in medical education. Medical Education Quartet, 357(9258), 792-796.

Wilson, M. (2003). Understanding the international ICT and development discourse: assumptions and implications. The South African Journal of Information and 
Communication 3. Retrieved January 31, 2011, from http://link.wits.ac.za/journal/j0301-merridy-fin.pdf

World Bank (2007). World development report 2007: Development and the next generation. Retrieved September 11, 2007, from http://econ.worldbank.org/external/default/main?pagePK=64165259\&theSiteP $\underline{K}=469372 \&$ piPK $=64165421 \&$ menuPK $=64166093 \&$ entity $\mathrm{ID}=000112742 \_20$ 060913111024.

Zheng, Y., \& Walsham, G. (2008). Inequality of what? Social exclusion in the esociety as capability deprivation. Information Technology \& People, 21(3), 222-243.

\section{Author Biography}

Cheryl Brown is a Lecturer in the Centre for Educational Technology at University of Cape Town where she teaches in the Masters in Education (ICTs) course. She has a $\mathrm{PhD}$ in Information Systems and is passionate about digital literacies and digital identities.

\section{Access and Use Survey 2007}

\section{Appendix}

Part A was "Access to ICTs", with the acronym ICTs (Information and Communication Technologies) to refer to computers, computer infrastructure (including the Internet), software, and associated technologies such as data-projectors and mobile phones. Students were asked five questions about their access to ICTs on their university campus and eight questions about their access to ICTs off campus. They were then asked nine questions about their experiences using ICTs.

Part B focused on "Using ICTs" and covered use socially, by students' lecturers and by the students in terms of their use of ICTs as part of their studies. The final section sought to capture information about the students themselves.

The eight open-ended questions were positioned at the end of each section and were phrased in various ways to capture positive, negative and neutral experiences. However despite the prompting, students didn't necessarily limit their responses to answering the question. The space was used variously to voice issues students' felt strongly about by either reiterating issues raised in the quantitative questions preceding the open answer section or raising new issues that hadn't emerged in the preceding questions. The entire survey is contained in Appendix 1 with an extract of the open ended questions highlighted in Table 0-1.

Table 0-1: Open-ended questions from the 2007 survey

\begin{tabular}{l|l} 
Survey question and number & Reference * \\
\hline Section A: Access on campus & \\
\hline How do you access ICTs ON your university campus? & \\
\hline A6: What makes it hard for you to access ICTs on campus? & Q1 \\
\hline $\begin{array}{l}\text { A7: What helps you in terms of your access to ICTs on } \\
\text { campus? }\end{array}$ & Q2 \\
\hline
\end{tabular}




\begin{tabular}{l|l}
\hline How do you access ICTs off campus? & \\
\hline A16: What makes it hard for you to access ICTs off campus? & Q3 \\
\hline $\begin{array}{l}\text { A17: What helps you in terms of your access to ICTs off } \\
\text { campus? }\end{array}$ & Q4 \\
\hline Section B: Using ICTs & \\
\hline B17: What don't you like about using ICTs for learning? & Q5 \\
\hline B18: What do you like about using ICTs for learning? & Q6 \\
\hline $\begin{array}{l}\text { B19: Are there any additional comments you would like to } \\
\text { make? }\end{array}$ & Q7
\end{tabular}

\section{Endnotes}

' University enrolments increased by $27 \%$ from 2000 to 2003 and the proportion of Black students rose by $40 \%$ from 1999 to 2005.

ii The 2005 drop-out rate is reported as 50\% and in 2010, our Deputy President quoted a $35 \%$ drop-out rate for undergraduate degree studies and a $70 \%$ drop-out rate for distance higher education.

iii The sample comprised four traditional and two comprehensive universities of both English and Afrikaans language mediums. Three were from historically advantaged and two from historically disadvantaged backgrounds with one institution a newly merged mix of the two. The institutions were also located across rural (two universities) and urban settings (four universities).

${ }^{\text {iv }}$ The headings in bold are my analytical concepts and the number in square brackets afterwards, that is, [Q6] indicates the number of the question from Gee's analytical framework.

${ }^{*}$ The graph represents the number of instances each particular Discourse was identified in the texts. Of the 840 individual respondents 221 exhibited more than one type of Discourse. 